\title{
PENYEBARAN BULU BABI (Sea Urchins) DI PERAIRAN PULAU MENJANGAN KECIL, KEPULAUAN KARIMUNJAWA, JEPARA
}

\author{
The Dispersal of Sea urchins in Menjangan Kecil Island, Karimunjawa Islands, Jepara.
}

\section{Fitria Hersiana Afifa, Supriharyono*) dan Pujiono Wahyu Purnomo}

Program Studi Manajemen Sumberdaya Perairan, Departemen Sumberdaya Akuatik Fakiltas Perikanan dan Ilmu Kelautan, Universitas Diponegoro

J1. Prof. Soedharto, SH, Tembalang, Semarang, Jawa Tengah - 50275, Telp/Fax. +6224 7474698

Email: fitriahersiana@gmail.com

\begin{abstract}
ABSTRAK
Echinodermata merupakan salah satu phylum yang memiliki peranan penting di perairan terumbu karang, seperti ditemukan di Perairan Pulau Menjangan Kecil. Peranan Bulu Babi di ekosistem terumbu karang berkaitan dengan pengendalian ekspansi algae. Penelitian dilaksanakan pada tanggal 19 dan 20 November 2016, dengan tujuan untuk mengetahui penyebaran Bulu Babi serta kelimpahan Bulu Babi pada kedalaman dan antar lokasi yang berbeda. Metode yang digunakan adalah metode eksplanatif. Stasiun pengukuran terdapat di zona muka dan belakang pulau yang terdapat terumbu karang, masing-masing stasiun dengan kedalaman yang berbeda. Pola penyebaran Bulu Babi dapat diketahui menggunakan formula $\mathrm{ID}=\mathrm{S}^{2} / \bar{x}$, berdasarkan rumus tersebut diketahui nilai ID (indeks dispersion) tiap kedalaman di dua lokasi yang berbeda. Hasil ID pada Lokasi A berbeda pada kedalaman $0-90 \mathrm{~cm}$ dan $90-140 \mathrm{~cm}$ ID $<1$, sedangkan kedalaman 140-170 $\mathrm{cm}$ dan $>170 \mathrm{~cm}$ ID $>1$. Hasil ID lokasi B pada empat kedalaman yang berbeda yaitu ID $>1$. Berdasarkan hasil ID tersebut dapat diketahui bagaimana pola penyebaran. Hal ini menunjukkan bahwa Bulu Babi di Pulau Menjangan Kecil sebagian besar hidup mengelompok pada kedalaman yang ekosistem terumbu karang masih cukup baik.
\end{abstract}

Kata Kunci: Pulau Menjangan Kecil; Penyebaran; Kelimpahan; Bulu Babi

\begin{abstract}
Echinoderm is one of the phylum that has an important role in the waters of the coral reefs, as found in the waters of the Menjangan Kecil Island. The role of the sea urchins in the coral reef ecosystem is related to the control of algae expansion. The study was conducted in $19^{\text {th }}$ and $20^{\text {th }}$ November 2016, with the objective of knowing the spread abundance of sea urchins at different depths and locations. The method that used was explanative method. The measuring stations are located in the back and forth zones of coral reefs, each with different depths. Spread pattern of sea urchins can be known using the formula $I D=S 2 / x$, based on the formula is known value of ID (dispersion index) each depth at two different location. Result ID at Location A at 0-90 cm and 90-140 cm is ID $<1$, while at 140-170 cm and $>170 \mathrm{~cm}$ is $I D>1$. The result of location ID B on four different depths is $I D>1$. Based on the ID results can be known how the pattern of dissemination. This indicates that the sea urchins in Menjangan Kecil Island live mostly in groups at the depths of which coral reef ecosystems are still quite good.
\end{abstract}

Keywords: Menjangan Kecil Island; Dispersal patterns; Abundanc; Sea Urchins

*) Penulis Penanggungjawab

\section{PENDAHULUAN}

Karimunjawa adalah kepulauan di Laut Jawa yang termasuk dalam Kabupaten Jepara, Jawa Tengah. Dengan luas daratan \pm 1.500 hektare dan perairan \pm 110.000 hektare, Karimunjawa kini dikembangkan menjadi pesona wisata Taman Laut yang mulai banyak digemari wisatawan lokal maupun mancanegara. Kepulauan Karimunjawa memiliki 27 pulau, salah satunya yaitu Pulau Menjangan Kecil. Pulau Menjangan Kecil terletak di sebelah Selatan Pulau Karimunjawa, yang memiliki luas 56,0 ha dengan 0,79\% daratan. Pulau Menjangan Kecil merupakan salah satu tujuan wisatalautyang memiliki keanekaragaman terumbu karang dan biota yang berasosiasi dengan terumbu karang.

Terumbu karang merupakan salah satu ekosistem perairan bagi berbagai jenis biota laut, salah satunya yaitu filum Echinodermata. Echinodermata berasal dari bahasa Yunani Echinos artinya duri, derma artinya kulit. Echinodermata adalah penghuni perairan dangkal, umumnya terdapat di terumbu karang dan padang lamun. Salah satu 
kelas yang terdapat dalam filum Echinodermata adalah Echinoidea. Salah satunya adalah bulu babi. Bulu babi umumnya hidup di daerah batu karang, lamun, dan juga pasir. Bulu babi memiliki cangkang yang keras dan bagian dalamnya bersisi lima simetris. Menurut Akerina et al., (2015), bulu babi jenis tertentu memiliki cangkang yang dilapisi oleh pigmen cairan hitam yang stabil. Selain memiliki cangkang yang keras, 95\% bagian tubuh bulu babi didominasi oleh duri-duri yang sangat rapuh dan sedikit beracun. Duri ini digunakan untuk bergerak, melindungi diri, serta mencapit makanan, dan untuk jenis-jenis tertentu mengandung racun.

Ekosistem terumbu karang merupakan bagian dari ekosistem laut karena menjadi sumber kehidupan bagi beranekaragam biota laut di perairan. Salah satu pulau dengan pesona terumbu karang yang indah yaitu Pulau Menjangan Kecil, Kepulauan Karimunjawa. Selain terumbu karang, ada berbagai biota yang hidup berasosiasi dengan terumbu karang. Salah satu biota laut yang ada di ekosistem terumbu karang adalah bulu babi. Berdasarkan ciri morfologi tersebut maka biota ini mempunyai kemampuan untuk bertahan di suatu lingkungan.

Pertimbangan pertama dilakukannya penelitian ini adalah dalam hal hubungan fungsional antara bulu babi dengan ekosistem terumbu karang. Salah satu faktor antropogenik yang mempengaruhi sebaran terumbu karang adanya ekspansi algae. Berlimpahnya bulu babi diperkirakan dapat mengendalikan ekspansi algae. Pengaruhnya terhadap ekosistem terumbu karang adalah dalam hal penguasaan area. Kelimpahan bulu babi dapat diperikirakan menjadi faktor yang dapat mengendalikan wilayah sebaran karang. Pertimbangan kedua terumbu karang banyak ditemukan hampir di seluruh luasan perairan di Pulau Menjangan Kecil yang perlu dikendalikan efek antropogenik. Pertimbangan ketiga yaitu adanya pengaruh kedalaman terhadap kelimpahan dan penyebaran bulu babi.

Tujuan dari penelitian ini adalah :

1. Mengetahui kelimpahan bulu babi antar lokasi penelitian

2. Mengetahui pola penyebaran bulu babi

3. Mengetahui pengaruh kedalaman terhadap kelimpahan bulu babi.

\section{MATERI DAN METODE PENELITIAN}

\section{Materi}

Obyek penelitian ini adalah terumbu karang dan bulu babi (Diadema). Pengamatan terumbu karang terkait dengan habitat bulu babi. Pengamatan terhadap bulu babi terkait dengan pengaruh kedalaman terhadap kelimpahan.

\section{Metode}

Metode penelitian yang digunakan dalam penelitian ini adalah eksplanasi. Menurut Bungin (2001), eksplanasi merupakan penelitian yang menjelaskan suatu generalisasi sampel terhadap populasinya atau menjelaskan hubungan, perbedaan atau pengaruh satu variabel dengan variabel yang lain.

Metode pengambilan sampel menggunakan metode purposive sampling, yaitu pengambilan sampel secara sengaja, sesuai dengan persyaratan sampel yang diperlukan dengan asumsi bahwa sampel yang diambil dapat mewakili populasi dari lokasi penelitian. Menurut Notoatmodjo (2002), metode purposive sampling yaitu penentuan lokasi dan responden dengan beberapa pertimbangan tertentu oleh peneliti, berdasarkan ciri atau sifat-sifat populasi yang sudah diketahui sebelumnya.

Lokasi sampling tersaji pada Gambar 1. Dalam hal ini dilakukan pada dua lokasi pengambilan sampel, yaitu lokasi A sebagai muka pulau (windwood) dan lokasi B sebagai belakang pulau (leewood). Lokasi tersebut dibedakan dengan empat kedalaman yang berbeda yaitu $(0-90 \mathrm{~cm}, 90-140 \mathrm{~cm}, 140-170 \mathrm{~cm}$, dan $>170 \mathrm{~cm})$. Perbedaan kedalaman ditujukan untuk mengkaji penyebaran Bulu Babi. Setiap kedalaman dilakukan sebanyak lima kali. Penentuan kedalaman dilakukan sesuai dengan batimetri dan dilakukan secara acak. Selain pengamatan bulu babi, dilakukan pula pemantauan terumbu karang dengan metode Line Transect. Pemantauan terumbu karang line transect mengacu pada Fachrul (2007), metode line transect digunakan untuk menggambarkan struktur komunitas karang dengan melihat tutupan karang hidup, karang mati, pasir, serta keberadaan biota lainnya. Penyebaran bulu babi dapat diketahui menggunakan formula ID $=\mathrm{S}^{2} / \bar{x}$, dimana ID (Indeks dispersi), $\mathrm{S}^{2}$ (ragam) dan $\bar{x}$ (rata-rata). Penyebran dapat ditentukan dari nilai ID, apabila ID $<1$ (regular) apabila ID $>1$ (mengelompok). Penyebaran atau distribusi individu dalam satu populasi bisa bermacam-macam, umumnya penyebaran memperlihatkan tiga pola, yaitu pola acak (random), pola mengelompok (clumped), dan pola teratur (regular). Untuk mendukung kegiatan utama terhadap kelimpahan dan penyebaran bulu babi dilakukan pengukuran variabel lingkungan. Variabel lingkungan seperti fisika kimia perairan yang diukur adalah temperatur, kecerahan, kedalaman, $\mathrm{pH}$, salinitas dilakukan secara in situ. Pengukuran dilakukan di setiap stasiun pengamatan dengan pengulangan sebanyak empat kali sesuai dengan penentuan lokasi sampling pengamatan bulu babi. 


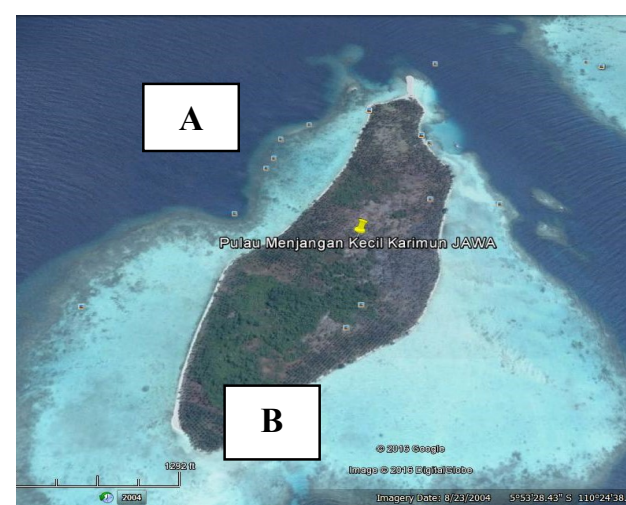

\section{Analisis Data}

Gambar 1. Penentuan lokasi sampling

Anova (Analysis of variances) digunakan untuk melakukan analisis perbandingan variable, analisis Anova dibantu menggunakan aplikasi SPSS. Dalam hal ini ditujukan untuk membandingan kelimpahan bulu babi yang diamati. Uji Anova dua arah digunakan untuk melihat pengaruh dari faktor kedalaman dan faktor zonasi terhadap distribusi bulu babi di Pulau Menjangan Kecil. Anova dua arah ini digunakan bila sumber keragaman yang terjadi tidak hanya karena satu faktor (perlakuan).

\section{HASIL DAN PEMBAHASAN}

\section{Hasil}

\section{Keadaan Umum Lokasi}

Karimunjawa adalah kepulauan di Laut Jawa yang termasuk dalam Kabupaten Jepara, Jawa Tengah. Dengan luas daratan \pm 1.500 hektare dan perairan \pm 110.000 hektare, Karimunjawa kini dikembangkan menjadi pesona wisata Taman Laut yang mulai banyak digemari wisatawan lokal maupun mancanegara. Kepulauan Karimunjawa memiliki 27 pulau, salah satunya yaitu Pulau Menjangan Kecil. Pulau Menjangan Kecil terletak di sebelah Selatan Pulau Karimunjawa, yang memiliki luas 56,0 ha dengan 0,79\% daratan. Pulau Menjangan Kecil merupakan salah satu tujuan wisata laut yang memiliki keanekaragaman terumbu karang dan biota yang berasosiasi dengan terumbu karang. Kepulauan Karimunjawa dapat dilihat pada Gambar 2.

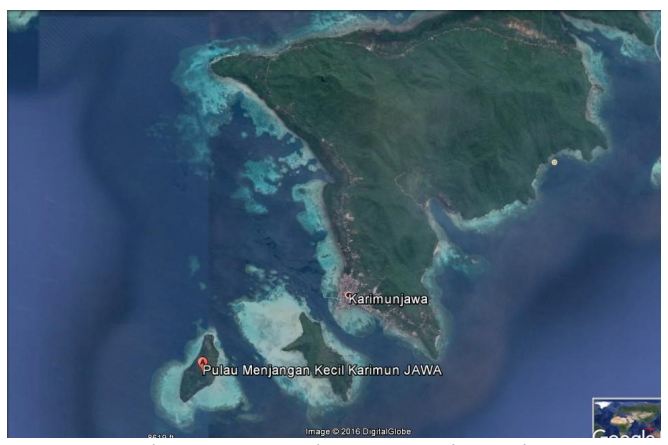

Gambar 2. Kepulauan Karimunjawa

\section{Wilayah Sebaran Bulu Babi}

\section{a. Kedalaman}

Kedalaman sangatlah penting dalam menentukan lokasi pengamatan, lokasi pengamatan dipetakan kedalam peta bathimetri. Kedalaman pengamatan berkisar antara 90 sampai $>170 \mathrm{~cm}$, dengan luasan berkisar antara 70 sampai 90 ha. Peta bathimetri pulau Menjangan Kecil, Karimunjawa dapat dilihat pada gambar 3. 


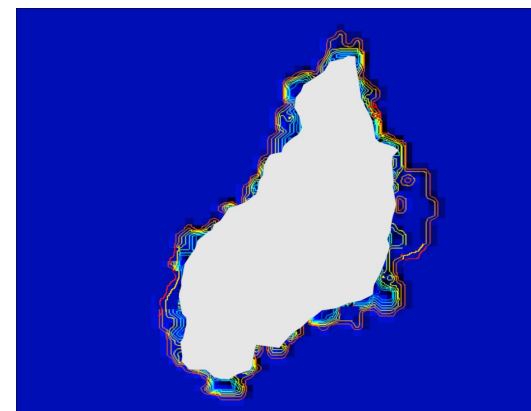

Gambar 3. Peta Bathimetri Pulau Menjangan Kecil

Berdasarkan peta tersebut, tiap kedalaman memiliki luasan yang berbeda. Luasan tersebut dapat dilihat menggunakan digitasi. Luasan tiap kedalaman tersaji dalam Tabel berikut:

Tabel 1. Luasan tiap kedalaman Pulau Menjangan Kecil, Kepulauan Karimunjawa

\begin{tabular}{lll}
\hline No & Kedalaman $(\mathrm{cm})$ & Luasan $($ ha $)$ \\
\hline 1 & 90 & 70.1 \\
2 & $90-140$ & 73 \\
3 & $140-170$ & 85.23 \\
4 & $>170$ & 88.27 \\
\hline
\end{tabular}

\section{b. Tipe Habitat Bulu babi}

Habitat bulu babi pada umumnya hidup di terumbu karang, tetapi ada pula yang hidup di pasir maupun karang mati. Tabel berikut akan megelompokkan berapa persenan bulu babi yang hidup baik di karang hidup, karang mati, dan lain-lain.

$\underline{\text { Tabel 2. Persentase bulu babi pada lokasi A dan lokasi B }}$

\begin{tabular}{|c|c|c|c|c|c|c|c|c|c|c|c|c|c|}
\hline \multirow{2}{*}{ Habitat } & \multicolumn{5}{|c|}{ A } & \multicolumn{6}{|c|}{ B } & \multirow[b]{2}{*}{$\bar{x}$} & \multirow[b]{2}{*}{$\overline{A B}$} \\
\hline & 1 & 2 & 3 & 4 & 5 & $\bar{x}$ & 1 & 2 & 3 & 4 & 5 & & \\
\hline KH (\%) & 55 & 55 & 60 & 60 & 60 & 58 & 55 & 55 & 60 & 60 & 60 & 58 & 58 \\
\hline KM (\%) & 25 & 15 & 20 & 20 & 25 & 21 & 15 & 25 & 20 & 25 & 25 & 22 & 21.5 \\
\hline PK (\%) & 5 & 5 & 5 & 5 & 5 & 5 & 5 & 5 & 5 & 5 & 5 & 5 & 5 \\
\hline P (\%) & 15 & 25 & 15 & 15 & 10 & 16 & 25 & 15 & 15 & 10 & 10 & 15 & 15.5 \\
\hline
\end{tabular}

Berdasarkan Tabel 2, bulu babi yang ditemukan di Pulau Menjangan Kecil umumnya ditemukan pada habitat terumbu karang. Bulu babi yang hidup baik di lokasi A maupun B lebih banyak di karang hidup (KH) sebesar 58\%, di karang mati (KM) sebesar 21.5\% sedangkan di pecahan karang (PK) dan pasir (P) sebesar 5\%, dan 15.5\%.

\section{c. Tutupan Terumbu Karang}

Terumbu karang merupakan habitat bagi bulu babi (Diadema sitosum), pada penelitian di Pulau Menjangan Kecil, Karimunjawa ini dilakukan pengamatan terumbu karang yang selanjutnya dilakukan perhitungan persentase tutupan terumbu karang. Hasil dari persentase tutupan karang dapat dilihat pada Tabel 3:

Tabel 3. Persentase Tutupan Terumbu Karang Lokasi A dan B

\begin{tabular}{lcccccccccc}
\multirow{2}{*}{$\begin{array}{c}\text { Kedalaman } \\
(\mathrm{cm})\end{array}$} & \multicolumn{1}{c}{$\mathrm{A}$} & \multicolumn{1}{c}{ Total } \\
\cline { 2 - 11 } & $\mathrm{KH}(\%)$ & $\mathrm{KM}(\%)$ & $\mathrm{PK}(\%)$ & $\mathrm{P}(\%)$ & $\begin{array}{c}\text { B } \\
(\%)\end{array}$ & $\mathrm{KH}(\%)$ & $\mathrm{KM}(\%)$ & $\mathrm{PK}(\%)$ & $\mathrm{P}(\%)$ & $\begin{array}{c}\text { Total } \\
(\%)\end{array}$ \\
\hline $0-90$ & 28 & 8 & 12 & 52 & 100 & 28 & 12 & 12 & 48 & 100 \\
$90-140$ & 32 & 8 & 20 & 40 & 100 & 36 & 8 & 12 & 44 & 100 \\
$140-170$ & 48 & 4 & 20 & 28 & 100 & 52 & 8 & 16 & 24 & 100 \\
$>170$ & 52 & 12 & 12 & 24 & 100 & 56 & 4 & 24 & 16 & 100 \\
Rata-Rata & 40 & 8 & 16 & 36 & 100 & 43 & 8 & 16 & 33 & 100 \\
\hline
\end{tabular}


Berdasarkan hasil pengukuran tutupan terumbu karang, pada kedalaman 0 sampai $90 \mathrm{~cm}$ dan 90 sampai 140 $\mathrm{cm}$ presentase pasir lebih besar, hal tersebut dikarenakan kedalaman dekat dengan tepi pantai yang memiliki kandungan pasir lebih banyak. Kedalaman selanjutnya karang hidup memiliki presentase lebih besar, karena karang hidup merupakan habitat dari bulu babi yang ada di Pulau Menjangan Kecil, Karimunjawa. Menurut Keputusan Menteri Lingkungan Hidup No. 4 Tahun 2001 mengenai kriteria baku kerusakan terumbu karang yang dilihat dari presentase karang hidup, presentase karang hidup pada penelitian ini baik di Lokasi A maupun B sebesar $40 \%$., yang berarti kondisi terumbu karang termasuk dalam kategori sedang.

\section{Kelimpahan Bulu Babi}

Pengamatan kelimpahan bulu babi dengan kedalaman yang berbeda, maka kelimpahan yang diperoleh pada setiap lokasi berbeda. Lokasi A (muka pulau) pada kedalaman 0 sampai $90 \mathrm{~cm}$ rata-rata bulu babi yaitu $31 / \mathrm{m}^{2}$, pada kedalaman 90 sampai $140 \mathrm{~cm}$ rata-rata bulu babi adalah $31.2 / \mathrm{m}^{2}$, pada kedalaman 140 sampai $170 \mathrm{~cm}$ rata-rata bulu babi yaitu $41.8 / \mathrm{m}^{2}$, sedangkan pada kedalaman lebih dari $170 \mathrm{~cm}$ rata-rata bulu babi yaitu 52.8/ $\mathrm{m}^{2}$. Lokasi B (belakang pulau) diamati dengan kedalaman yang sama. Kedalaman 0 sampai $90 \mathrm{~cm}$ rata-rata bulu babi yaitu $35 / \mathrm{m}^{2}$, pada kedalaman 90 sampai $140 \mathrm{~cm}$ rata-rata bulu babi adalah $31.6 / \mathrm{m}^{2}$, pada kedalaman 140 sampai $170 \mathrm{~cm}$ rata-rata bulu babi yaitu $46.8 / \mathrm{m}^{2}$, sedangkan pada kedalaman lebih dari $170 \mathrm{~cm}$ rata-rata bulu babi yaitu 50.4/ $\mathrm{m}^{2}$. Hasil kelimpahan bulu babi dapat dilihat pada Tabel 4

Tabel 4. Kelimpahan Bulu Babi (Diadema sitosum) di Lokasi A dan B

\begin{tabular}{lrrrrrrrrrrrrr}
\hline & \multicolumn{1}{c}{ A } & \multicolumn{1}{c}{ B } \\
\cline { 2 - 13 } Kedalaman (cm) & \multicolumn{1}{c}{ Pengulangan } \\
\cline { 2 - 13 } & 1 & 2 & 3 & 4 & 5 & $\bar{x}$ & 1 & 2 & 3 & 4 & 5 & $\bar{x}$ \\
\hline $0-90$ & 25 & 33 & 38 & 28 & 31 & 31 & 31 & 23 & 36 & 38 & 47 & 35 \\
$90-140$ & 32 & 28 & 39 & 30 & 27 & 31.2 & 26 & 29 & 27 & 37 & 39 & 31.6 \\
$140-170$ & 29 & 37 & 33 & 44 & 66 & 41.8 & 39 & 51 & 45 & 41 & 58 & 46.8 \\
$>170$ & 40 & 62 & 42 & 62 & 58 & 52.8 & 48 & 46 & 49 & 46 & 63 & 50.4 \\
\hline
\end{tabular}

Hasil kelimpahan bulu babi tersebut selanjutnya dilakukan analisis data. Analisis data yang dilakukan menggunakan uji Anova dua arah. Uji ini dibantu menggunakan aplikasi SPSS. Uji ini bertujuan untuk melihat pengaruh dari zona dan kedalaman terhadap kelimpahan bulu babi. Hasil pengolahan data dapat dilihat pada Tabel berikut:

Tabel 5. Analisis menggunakan Anova dua arah

\begin{tabular}{lcrrrr}
\hline Source & $\begin{array}{c}\text { Type III Sum of } \\
\text { Squares }\end{array}$ & Df & Mean Square & \multicolumn{1}{c}{ F } & \multicolumn{1}{c}{ Sig. } \\
\hline Corrected Model & $2877.175^{\mathrm{a}}$ & 7 & 411.025 & 5.427 & .000 \\
Intercept & 64240.225 & 1 & 64240.225 & 848.196 & .000 \\
Zona & 30.625 & 1 & 30.625 & .404 & .529 \\
Kedalaman & 2759.875 & 3 & 919.958 & 12.147 & .000 \\
Zona * Kedalaman & 86.675 & 3 & 28.892 & .381 & .767 \\
Error & 2423.600 & 32 & 75.738 & & \\
Total & 69541.000 & 40 & & & \\
Corrected Total & 5300.775 & 39 & & & \\
\hline
\end{tabular}

Berdasarkan Tabel 5 di atas, dapat diketahui pengaruh zona dan kedalaman terhadap kelimpahan bulu babi. Hasil dinyatakan signifikan apabila $<0.05$ dan tidak signifikan apabila hasil $>0.05$. Hasil pengolahan dari Zona memiliki nilai signifikan 0.529, ini menunjukkan bahwa zona tidak mempengaruhi jumlah atau kelimpahan dari bulu babi. Hasil pengolahan dari Zona dan kedalaman memiliki nilai signifikan 0.767 , ini menunjukkan bahwa zona dan kedalaman tidak berkaitan dalam mempengaruhi kelimpahan bulu babi. Hasil pengolahan dari Kedalaman memiliki nilai signifikan 0.000 hal ini berarti menunjukkan bahwa kedalaman signifikan atau mempengaruhi kelimpahan bulu babi yang ada di Pulau Menjangan Kecil, Kepulauan Karimunjawa.

\section{Rata-Rata Ukuran Diameter Bulu Babi}

Berdasarkan pengamatan kelimpahan bulu babi di Pulau Menjangan Kecil, dapat dikatakan cukup melimpah. Bulu babi yang diamati tidak terlepas dengan ukuran diameter bulu babi. Ukuran diameter bulu babi pada lokasi A dan B tersaji pada Tabel 6:

Tabel 6. Rata-rata ukuran diameter bulu babi pada Lokasi A dan B 


\begin{tabular}{lllllllll}
\hline \multirow{2}{*}{$\begin{array}{l}\text { Ukuran } \\
(\mathrm{cm})\end{array}$} & \multicolumn{9}{c}{ Kedalaman $(\mathrm{cm})$} & \multicolumn{5}{c}{ B } \\
\cline { 2 - 9 } & $0-90$ & $90-140$ & $140-170$ & $>170$ & $0-90$ & $90-140$ & $140-170$ & $>170$ \\
\hline $1-5$ & 30 & 35 & 35 & 30 & 30 & 30 & 39 & 37 \\
$6-10$ & 60 & 65 & 65 & 68 & 55 & 65 & 68 & 69 \\
$11-15$ & 45 & 45 & 48 & 47 & 40 & 45 & 47 & 47 \\
$16-20$ & 25 & 25 & 35 & 36 & 35 & 37 & 38 & 37 \\
$20-25$ & 20 & 20 & 25 & 25 & 20 & 25 & 25 & 30 \\
\hline
\end{tabular}

Tabel 6 tersebut menunjukan rata-rata ukuran diameter bulu babi pada lokasi A dan B, dari hasil tersebut ratarata yang ditemukan berukuran $6-10 \mathrm{~cm}$, baik di lokasi A maupun lokasi B.

\section{Penyebaran Bulu Babi}

Berdasarkan data kelimpahan bulu babi, dapat diketahui pola penyebaran bulu babi antara lokasi A dan lokasi B. Pola penyebaran bulu babi dapat dilihat pada Tabel 7 dan 8

Tabel 7. Pola penyebaran bu;u babi Lokasi A

\begin{tabular}{lllllllll}
\hline Kedalaman & 1 & 2 & 3 & 4 & 5 & Ragam & Rataan & ID \\
\hline $0-90$ & 25 & 33 & 38 & 28 & 31 & 24.5 & 31.0 & 0.79 \\
$90-140$ & 32 & 28 & 39 & 30 & 27 & 22.7 & 31.2 & 0.73 \\
$140-170$ & 29 & 37 & 33 & 44 & 66 & 213.7 & 41.8 & 5.11 \\
$>170$ & 40 & 62 & 42 & 62 & 58 & 119.2 & 52.8 & 2.26 \\
\hline
\end{tabular}

Tabel 8. Pola penyebaran bulu babi Lokasi B

\begin{tabular}{lllllllll}
\hline Kedalaman & 1 & 2 & 3 & 4 & 5 & Ragam & Rataan & ID \\
\hline $0-90$ & 31 & 23 & 36 & 38 & 47 & 78.5 & 35 & 2.24 \\
$90-140$ & 26 & 29 & 27 & 37 & 39 & 35.8 & 31.6 & 1.13 \\
$140-170$ & 39 & 51 & 45 & 41 & 58 & 60.2 & 46.8 & 1.29 \\
$>170$ & 48 & 46 & 49 & 46 & 63 & 51.3 & 50.4 & 1.02 \\
\hline
\end{tabular}

Berdasarkan hasil perhitungan pada Tabel 7 dan 8 dapat diketahui pola penyebaran dari nilai ID (indeks dispersion). Nilai ID pada Lokasi A kedalaman 0-90 $\mathrm{cm}$ adalah 0.79, 90-140 cm adalah 0.73, 140-170 cm adalah 5.11 dan kedalaman lebih dari $170 \mathrm{~cm}$ 2.26. Nilai ID lokasi B pada kedalaman 0-90 cm adalah 2.24, kedalaman 90-140 cm adalah 1.13, kedalaman 140-170 cm sebesar 1.29, sedangkan kedalaman lebih dari $170 \mathrm{~cm}$ adalah 1.02 . Berdasarkan nilai ID tersebut dapat diketahui bagimana pola penyebaran. Apabila nilai ID $<1$ maka pola sebaran termasuk regular (tidak mengelompok), hal tersebut sesuai dengan nilai ID pada lokasi A di kedalaman 0-90 cm dan 90-140 cm dimana nilai ID pada kedalaman tersebut kurang dari 1. Apabila nilai ID $>1$ maka pola sebaran tersebut termasuk mengelompok. Nilai ID pada lokasi A kedalaman $140-170 \mathrm{~cm}$ dan lebih dari $170 \mathrm{~cm}$ termasuk dalam kategori mengelompok, sedangkan pada lokasi B semua kedalaman memiliki pola sebaran mengelompok.

\section{Faktor Lingkungan}

Faktor lingkungan sangat mempengaruhi kehidupan biota yang ada di perairan. Faktor lingkungan yang diukur pada penelitian ini yaitu faktor fisika dan kimia perairan. Faktor fisika dan kimia yang diukur yaitu suhu, kecerahan, salinitas, dan derajat keasaman (pH). Pengukuran ini dilakukan pada dua lokasi yaitu lokasi A dan lokasi B, pada setiap titik sampling pengamatan. Hasil dari pengukuran kualitas air tersaji pada Tabel 9.

Tabel 9. Pengukuran Faktor Lingkungan

\begin{tabular}{|c|c|c|c|c|c|c|c|c|c|c|}
\hline \multirow{3}{*}{ Parameter } & \multicolumn{5}{|c|}{$\mathrm{A}$} & \multicolumn{5}{|c|}{ B } \\
\hline & \multicolumn{5}{|c|}{ Stasiun } & \multicolumn{5}{|c|}{ Stasiun } \\
\hline & 1 & 2 & 3 & 4 & 5 & 1 & 2 & 3 & 4 & 5 \\
\hline Temperatur & 29 & 29 & 28 & 29 & 29 & 29 & 29 & 29 & 29 & 29 \\
\hline
\end{tabular}




\begin{tabular}{lllllllllll}
\hline$\left({ }^{\circ} \mathrm{C}\right)$ & & & & & & & & & & \\
Kecerahan & $\sim$ & $\sim$ & $\sim$ & $\sim$ & $\sim$ & $\sim$ & $\sim$ & $\sim$ & $\sim$ & $\sim$ \\
$\begin{array}{l}\text { Salinitas } \\
(\% \circ)\end{array}$ & 34 & 34 & 34 & 34 & 34 & 34 & 34 & 34 & 34 & 34 \\
$\mathrm{pH}$ & 6 & 6 & 6 & 6 & 6 & 6 & 6 & 6 & 8 & 8 \\
\hline
\end{tabular}

Berdasarkan hasil pengukuran kualitas air tersebut pada lokasi A suhu air berkisar $29^{\circ} \mathrm{C}$. Kecerahannya tak terhingga karena kondisi perairan yang cerah sehingga masih terlihat lempengan sechi disc. Salinitas pada lokasi A yaitu 34\% $\%$, sedangkan $\mathrm{pH}$ (derajat keasaman) lokasi A yaitu 6. Pengukuran kualitas air pada Lokasi B tidak jauh berbeda, suhu pada lokasi B yaitu $29^{\circ} \mathrm{C}$. Kecerahan tak terhingga. Salinitas pada lokasi B yaitu $34^{\circ} \% \circ$, sedangkan pH (derajat keasaman) lokasi B yaitu 6 dan 8 .

\section{Pembahasan \\ Habitat Bulu Babi}

Ekosistem terumbu karang merupakan ekosistem laut yang menjadi sumber kehidupan bagi beraneka ragam biota laut, hal ini selaras dengan Dahuri (1999), ekosistem terumbu karang merupakan bagian dari ekosistem laut karena menjadi sumber kehidupan bagi beraneka ragam biota laut . Ekosistem ini terdapat di laut dangkal yang hangat dan bersih, dan merupakan perairan paling produktif di perairan laut tropis, serta memiliki keanekaragaman hayati yang sangat tinggi, salah satunya adalah bulu babi. Bulu babi merupakan biota ke dalam filum Echinoidea. Habitat Echinoidea pada daerah pantai atau dasar laut di kedalaman 100 sampai $5000 \mathrm{~m}$ atau di bawah garis batas surut terendah. Distribusinya sangat luas, terutama pada zona intertidal. Menurut Storer dan Usinger (1958), habitat Echinoidea pada daerah pantai atau dasar laut di kedalaman 100 sampai $5000 \mathrm{~m}$ atau di bawah garis batas surut terendah. Distribusinya sangat luas, terutama pada zona intertidal. Beberapa jenis Echinoidea hidup dalam sumursumuran di daerah pantai atau di bawah rumput laut, ada juga yang membenamkan diri dalam tanah liat di muara sungai atau di bawah karang-karang yang lunak.

Bulu babi di Pulau Menjangan Kecil, Kepulauan Karimunjawa pada umumnya hidup di daerah karang hidup. Hal ini selaras dengan pernyataan Hyman (1955) dalam Ratna (2002), kebanyakan bulu babi beraturan hidup pada substrat yang keras,yakni batu-batuan atau terumbu karang dan hanya sebagian kecil yang menghuni substrat pasir dan lumpur, karena pada kondisi demikian kaki tabung sulit untuk mendapatkan tempat melekat.

Bulu babi di Pulau Menjangan Kecil hidup pada ekosistem terumbu karang (zona pertumbuhan alga) dan lamun. Bulu babi dapat di temui pada daerah intertidal, menurut Aziz (1995) dalam Hasan (2002), bulu babi dapat ditemui dari daerah intertidal sampai kedalaman $10 \mathrm{~m}$ dan merupakan penghuni sejati laut dengan batas toleransi salinitas antara $30-34 \%$.

Salah satu habitat yang cocok dengan bulu babi adalah terumbu karang. Terumbu karang adalah ekosistem perairan tropis yang sangat penting dan produktif di lingkungan perairan. Menurut Dahuri dan Dutton (2000), Indonesia adalah salah satu negara yang memiliki sumberdaya terumbu karang tertinggi di dunia. Potensi ini menyokong kehidupan bagi jutaan penduduknya yang hidup di wilayah pesisir. Terumbu karang pada penelitian ini diamati presentase tutupannya.

\section{Kelimpahan Bulu Babi}

Echinoidea merupakan salah satu kelas dari Phylum Echinodermata. Termasuk Phylum Echinodermata karena Echinoidea merupakan binatang laut yang tubuhnya dipenuhi duri tersusun atas zat kapur. Ada yang berduri panjang dan lancip, salah satu biota yang termasuk dalam kelas Echinoidea adalah bulu babi. Bulu dan ada pula yang berduri pendek dan tumpul. Menurut Campbell (2003), Echinoidea hidup pada batuan atau lumpur di tepi pantai atau dasar perairan. Makanannya adalah rumput laut, hewan yang telah mati, biasanya nocturnal. Permukaan tubuh hewan ini berduri panjang.

Bulu babi yang ditemukan dalam penelitian ini di Pulau Menjangan Kecil, Kepulauan Karimunjawa adalah jenis Diadema setosum. Bulu babi di Pulau Menjangan Kecil sangatlah banyak, bahkan penduduk lokal menyebut Pulau Menjangan Kecil sebagai rumah dari bulu babi. Berdasarkan hasil pengamatan kelimpahan bulu babi, bulu babi yang banyak ditemukan dari lokasi A dan B yaitu pada kedalaman 140 sampai dengan $170 \mathrm{~cm}$. Hal tersebut sesuai dengan presentase tutupan terumbu karang dimana banyak ditemukan karang hidup pada kedalaman 140 sampai dengan 170 cm, sehingga kedalaman mempengaruhi dari kelimpahan bulu babi yang ada di Pulau Menjangan Kecil. Kedalamam mempengaruhi kelimpahan bulu babi tidak terlepas dengan habitat bulu babi. Menurut Menurut Hyman (1955) dalam Ratna (2002) bahwa bulu babi termasuk hewan benthonic, ditemui di semua laut dan lautan dengan batas kedalaman antara 0-8000 m. Kebanyakan bulu babi beraturan hidup pada substrat yang keras,yakni batu-batuan atau terumbu karang dan hanya sebagian kecil yang menghuni substrat pasir dan lumpur, karena pada kondisi demikian kaki tabung sulit untuk mendapatkan tempat melekat.

Kelimpahan bulu babi dianalisis menggunakan Anova dua arah. Analisis Anova dua arah menunjukkan bahwa kedalaman signifikan atau berpengaruh pada kelimpahan bulu babi. Menurut Umagap (2013), habitat Echinoidea pada daerah pantai atau dasar laut pada kedalaman 100 sampai $5000 \mathrm{~m}$ atau di bawah garis batas surut terendah. 
Distribusinya sangat luas, terutama pada zona intertidal. Beberapa jenis Echinoidea hidup di daerah pantai atau di bawah rumput laut, ada juga yang membenamkan diri dalam tanah liat di muara sungai atau di bawah karang-karang yang lunak.

\section{Penyebaran Bulu Babi}

Bulu babi adalah salah satu jenis organisme dari laut yang banyak ditemukan diseluruh pantai di Indonesia. Bulu babi dapat ditemukan mulai dari daerah pasang surut sampai perairan yang dalam. Penyebaran lokal bulu babi sangat tergantung kepada perkembangan faktor habitat dan makanan.

Berdasarkan kelimpahan bulu babi, dapat diketahui pola penyebaran bulu babi. Pola penyebaran bulu babi yang dihitung sesuai dengan rumus yang ditemukan oleh Ludwig dan Reynold (1988) yaitu $\mathrm{ID}=\mathrm{S}^{2} / \overline{\boldsymbol{X}}$. Dimana ID (indeks dispersion) $S^{2}$ (ragam), dan $\bar{x}$ (rata-rata).

Menurut Nybakken (1988) dalam Gani et al., (2013), penyebaran merupakan suatu pola atau tata ruang individu yang satu relative terhadap yang lain dalam populasi. Penyebaran atau distribusi individu dalam satu populasi bisa bermacam-macam, umumnya penyebaran memperlihatkan tiga pola, yaitu pola acak (random), pola mengelompok (clumped), dan pola teratur (regular). Tiap-tiap jenis hewan tentunya mempunyai pola sebaran yang berbeda-beda tergantung pada model reproduksi dan lingkungan.

Pola penyebaran bulu babi pada penelitian ini ada dua macam yaitu mengelompok pada Lokasi B (belakang pulau) karena nilai ID $>1$, sedangkan di Lokasi A ada yang mengelompok yaitu pada kedalaman 140-170 cm dan $>170$ $\mathrm{cm}$, adapula pola sebaran yang regular (teratur) pada kedalaman $0-90 \mathrm{~cm}$ dan $90-140 \mathrm{~cm}$.

Penyebaran bulu babi dapat dipengaruhi oleh kondisi habitat maupun lingkungan dari biota tersebut. Menurut Suwigyo et al., (2005), menyebarnya macam-macam biota laut misalnya bulu babi dan hewan-hewan lainnya di karenakan kondisi lingkungan, oleh sebab itu bulu babi dapat hidup, tumbuh dan menyebar di perairan pantai seiring dengan lingkungan yang mempengaruhinya. Bulu babi dapat menyebar pada daerah-daerah tertentu antara lain pada terumbu karang, lamun, hutan mangrove dan ganggang.

Faktor yang mendukung kelangsungan hidup biota juga menentukan penyebaran dari biota. Sebagaimana yang dijelaskan oleh Odum (1996), faktor-faktor yang mendukung kelangsungan hidup suatu biota laut dapat pula menentukan keberadaan serta penyebaran dari biota (Echinoidae) tersebut, sehingga penyebaran biota di alam sangat bergantung pada keadaan lingkungan. Penyebaran merupakan penanda interaksi keberadaan biota dalam lingkungan yang ditujukan dengan berbagai pola yang terbentuk dari hasil interaksi.

\section{Faktor Lingkungan}

Faktor lingkungan sangatlah mempengaruhi kehidupan biota laut termasuk bulu babi. Faktor fisika dan kimia yang diukur yaitu temperatur, kecerahan, salinitas, derajat keasaman $(\mathrm{pH})$ serta kedalaman. Pengukuran faktor fisika dan kimia salah satunya adalah temperatur. Temperatur dilakukan pada setiap lokasi titik pengamatan. Temperatur yang di dapat yaitu berkisar antar $28^{\circ} \mathrm{C}$ sampai dengan $29^{\circ} \mathrm{C}$. Temperatur tersebut cocok untuk bulu babi dan habitatnya yaitu terumbu karang, walaupun demikian bulu babi tidak memiliki adaptasi khusus terhadap perubahan suhu. Menurut Aziz (1987), Bulu babi tidak memiliki adaptasi khusus terhadap peningkatan suhu diatas ambang batas maksimum yaitu $36^{\circ} \mathrm{C}$ sampai $40^{\circ} \mathrm{C}$.

Faktor lingkungan yang lain yaitu derajat keasaman $(\mathrm{pH})$. Derajat keasaman yang diukur pada setiap titik pengamatan yang ada di dua lokasi, pada lokasi A nilai $\mathrm{pH}$ (derajat keasaman) adalah 6, sedangkan pada lokasi $\mathrm{B}$ nilai pH adalah 6 dan 8. Menurut MenLH (2004), perairan ideal bagi bulu babi memiliki pH air berkisar antara 7.5 - 8.5.

Faktor lingkungan selanjutnya adalah kedalaman. Kedalaman sangat berpengaruh bagi kelimpahan bulu babi. Kedalaman bulu babi pada penelitian ini berkisar antara $90 \mathrm{~cm}$ sampai dengan lebih dari $170 \mathrm{~cm}$. Menurut Umagap (2013), habitat Echinoidea pada daerah pantai atau dasar laut pada kedalaman 100 sampai $5000 \mathrm{~m}$ atau di bawah garis batas surut terendah. Distribusinya sangat luas, terutama pada zona intertidal. Beberapa jenis Echinoidea hidup dalam sumur-sumuran di daerah pantai atau di bawah rumput laut, ada juga yang membenamkan diri dalam tanah liat di muara sungai atau di bawah karang-karang yang lunak.

\section{KESIMPULAN \\ Kesimpulan}

Kesimpulan yang diperoleh dari penelitian Penyebaran Bulu Babi (Sea Urchins) di Pulau Menjangan Kecil, Kepulauan Karimunjawa, Jepara adalah sebagai berikut:

1. Bulu babi yang ditemukan di Pulau Menjangan Kecil hanya satu spesies yaitu Diadema setosum. Bulu babi ini merupakan biota yang sangat banyak ditemukan. Rata- rata terbesar jumlah bulu babi di Lokasi A adalah 52.8, dan pada lokasi B adalah 50.4.

2. Pola penyebaran bulu babi di Pulau Menjangan Kecil sebagian besar yaitu mengelompok (clumped) terdapat pada lokasi B, sedangkan lokasi A ada yang reguler adapula yang mengelompok. 
3. Adanya pengaruh kedalaman terhadap kelimpahan bulu babi. Bulu babi cenderung hidup dengan kedalaman yang cukup dalam $(140-170 \mathrm{~cm})$ dan $>170 \mathrm{~cm}$, serta habitat bulu babi pada umunya di terumbu karang.

\section{UCAPAN TERIMAKASIH} artikel.

Penulis sampaikan terimakasih kepada Dr. Ir. Haeruddin, MSi yang telah memberikan masukan dalam penulisan

\section{DAFTAR PUSTAKA}

Akerina, F.O., Tati N., dan Ruddy S. 2015. Isolasi dan Karakterisasi Senyawa Antibakteri dari Bulu

Babi. Fakultas Perikanan dan Ilmu Kelautan Institut Pertanian Bogor. Vol18(1).

Aziz, A. 1987. Makanan dan cara makan berbagai jenis Bulu Babi.Oseana 12 (4): 91100.

Burhan, Bungin, 2001. Metodologi Penelitian Kualitatif. Jakarta. PT. Raja Grafindo Persada, hal. 231.

Campbell, N.A., Reece, J.B., dan Nitchel, L.G. (2003). Biologi: Edisi Kelima Jilid 2. Jakarta:Erlangga.

Dahuri, R., 1999, Kebijakan dan Strategi Pengelolaan Terumbu Karang, Lokakarya Pengelolaan dan IPTEK Terumbu Karang Indonesia, Jakarta.

Dahuri, R. and I.M. Dutton. 2000. "Integrated Coastal and Marine Management Enters a New Era in Indonesia," Integrated Coastal Zone Management: 1, 1116.

Fachrul, M, F, 2007. Metode Sampling Bioekologi. Bumi Aksara : Jakarta

Gani, L. A., Nuraini S., dan Zulkifli A. 2013. Asosiasi dan Pola Sebaran Bulu Babi (Echinoidea) di Maregam Kota Tidore Kepulauan. Jurnal Bioedukasi. Vol 2. No. 1

Pantai

Hasan F. 2002. Pengaruh konsentrasi garam terhadap mutu produk fermentasi gonad bulu babi jenis Tripneustes gratilla (L) [skripsi]. Bogor :Departemen Teknologi Hasil Perairan. FakultasPerikanan dan Ilmu Kelautan. Institut Pertanian Bogor.

Kementrian Lingkungan Hidup. 2001. Kriteria Baku Kerusakan Terumbu Karang

Notoatmodjo, S. 2002. Metodologi Penelitian Kesehatan. Rineka Cipta, Jakarta, 208hal.

Odum, E.P. 1993. Dasar-Dasar Ekologi. Edisi ketiga .Gajah mada University Press. Jogjakarta. H.

Ratna. 2002. Pengaruh Penambahan Gula dan Lama Fermentase Terhadap Mutu Pasta Fermentasi Gonad Bulu Babi Diadema setosum dengan Lactobacillus plantarum sebagai Kultur Starter.Skripsi Institut Pertanian Bogor. Bogor.

Suwignyo, W. M., dan Pustekom. 2005. Avertebrata Air Jilid I. Swadaya Jakarta

Umagap, W.A. Keragaman Spesies Landak Laut (Echinoidea) di Perairan Dofa, KabupatenKepulauan Jurnal Bioedukasi. Vol 1. No.2.

Sula. 2013. 